\title{
Consideration of the Optimum pH for the Analysis of Serum $p$-Phenylenediamine Oxidase Activity in Thoroughbred Horses
}

\author{
Masahiro OKUMURA, Makoto ASANO, and Toru FUJINAGA \\ Laboratory of Veterinary Surgery, Department of Veterinary Clinical Sciences, Graduate School of Veterinary Medicine, Hokkaido \\ University, Sapporo 060, Hokkaido, Japan \\ (Received 11 March 1996/Accepted 19 November 1996)
}

ABSTRACT. The optimum $\mathrm{pH}$ for the measurement of serum $p$-phenylenediamine oxidase (Ox) activity was given ( $\mathrm{pH}$ 6.6), and the relationship between serum Ceruloplasmin $(\mathrm{Cp})$ concentration and its Ox activity was established in healthy adult horses. In adult horses, serum antigenic $\mathrm{Cp}$ concentrations were measured by the single radial immunodiffusion (SRID) method with the affinity-purified antibody to equine plasma $\mathrm{Cp}$ and compared with its Ox activity. Efficient co-relation between $\mathrm{Cp}$ concentration and Ox activity in the sera $(\mathrm{r}=0.93)$ and its $\mathrm{Ox} / \mathrm{Cp}$ ratio were given. These results might contribute to the calculation of antigenic $\mathrm{Cp}$ concentration from its $\mathrm{Ox}$ activity, the analysis of holo-Cp content in serum, and the research for copper metabolism in Thoroughbred horses. - KEY wORDS: ceruloplasmin, equine, oxidase.

J. Vet. Med. Sci. 59(2): 137-139, 1997

Deficiency and excess of trace minerals, such as copper, zinc, selenium, and cobalt, are emphasized the importance for maturity of musculoskeletal system in growing animals, and are thought to cause the insufficiency of economic performance of livestock, especially cattle, porcine and avian. In equine medicine, deficiency of trace minerals is thought to be one of major causes of developmental orthopedic diseases [13]. Particularly, copper, one of these minerals, was pointed up as a cause of osteochondrosis and other developmental disorders in horses [4-6, 13].

Ceruloplasmin, which was named by Holmberg and Laurell in 1948 [10], is a glycoprotein containing bluecolored copper in mammalian blood plasma. Ceruloplasmin is one of major plasma proteins, but its properties easily change. For this difficult nature, there have been many reports on the methods for purification and characterization $[7,9,14,16,17]$ in some kinds of animals $[7,12,15,20]$. However, only few reports were found to isolate and characterize equine $\mathrm{Cp}[16,18,20]$.

Ceruloplasmin is a marker for copper metabolism [10], and used for the evaluation of copper deficiency [11]. Usually, serum $\mathrm{Cp}$ concentration is indirectly evaluated by measurement of $p$-phenylenediamine Ox activity. However, the discrepancies between the units of $p$-phenylenediamine Ox per unit of $\mathrm{Cp}$ were found, and thought to represent a difference of the $\mathrm{pH}$ of the condition buffer used, which were $\mathrm{pH} 5.2$ to 6.7 [6]. In addition, the optimum $\mathrm{pH}$ for the measurement of $p$-phenylenediamine $\mathrm{Ox}$ was varied in some kinds of animals, including human ( $\mathrm{pH} 5.90)$, rat ( $\mathrm{pH}$ 6.20), fowl ( $\mathrm{pH} 6.30)$, rabbit ( $\mathrm{pH} 6.40)$, bovine $(\mathrm{pH} 6.43)$, guinea pig ( $\mathrm{pH}$ 6.47), and donkey ( $\mathrm{pH}$ 6.60) [2], and that in Thoroughbred horses is unknown.

In the present study, the optimum $\mathrm{pH}$ for the analysis of equine plasma $\mathrm{Cp}$ oxidase activity was considered using $p$ phenylenediamine $\mathrm{Ox}$ in serum from adult Thoroughbred horses, and the ratio of its $\mathrm{Ox}$ activity to antigenic $\mathrm{Cp}$ concentration measured directly by the immunological method, was estimated.

Serum Ox activity to $p$-phenylenediamine was determined by the method reported by Bingley and Dick [3], and the
Table 1. Serum oxidase activity $\left(\mathrm{A}_{530}\right)$ at each $\mathrm{pH}(\mathrm{pH} 5.0$ to 7.5$)$ of $0.1 \mathrm{M}$ acetate buffer

\begin{tabular}{cc}
\hline $\mathrm{pH}$ & $\mathrm{A}_{530}$ \\
\hline 5.0 & $0.284 \pm 0.057$ \\
5.5 & $0.408 \pm 0.094$ \\
6.0 & $0.507 \pm 0.117$ \\
6.2 & $0.561 \pm 0.116$ \\
6.4 & $0.737 \pm 0.165$ \\
6.6 & $0.757 \pm 0.186$ \\
6.8 & $0.690 \pm 0.120$ \\
7.0 & $0.606 \pm 0.109$ \\
7.5 & $0.544 \pm 0.073$ \\
\hline
\end{tabular}

The values of $A_{530}$ indicated mean \pm S.D.

absorption (530 nm; A530) of the mixture was given as its Ox activity. The optimum $\mathrm{pH}$ of $0.1 \mathrm{M}$ acetate buffer for this assay was investigated at serial range from $\mathrm{pH} 5.0$ to 7.5 using acetate buffer (Table. 1 \& Fig. 1).

Equine plasma $\mathrm{Cp}$ was isolated by ammoniumprecipitation, DE-52 anionexchange chromatography and EAH-Sepharose 4B chromatography [18]. Antibody to equine $C p$ was purified by equine $C p$ binding sepharose $4 B$ affinity chromatography from the antiserum to equine plasma Cp raised in rabbits. The SRID method [18], using purified rabbit antibody to equine $\mathrm{Cp}$ mentioned above, was used to measure serum $\mathrm{Cp}$ concentration. Protein concentration was determined by measuring at the A280 of equine $\mathrm{Cp}$ [16].

In serum samples of clinically healthy adult horses (thoroughbred, $\mathrm{n}=25 ; 8.5 \pm 4.6$ years old), $\mathrm{Cp}$ concentration and its Ox activity were given. There was a high correlation between the serum $\mathrm{Cp}$ concentration and its Ox activity in these horses (correlation coefficient $=0.93$ ) and the following formula was calculated (Fig. 2).

$$
\mathrm{A}_{530}=0.019 \times \text { serum } \mathrm{Cp}(\mathrm{mg} / \mathrm{d} l)-0.22
$$

The Ox activity is known to be affected by the $\mathrm{pH}$ of the 


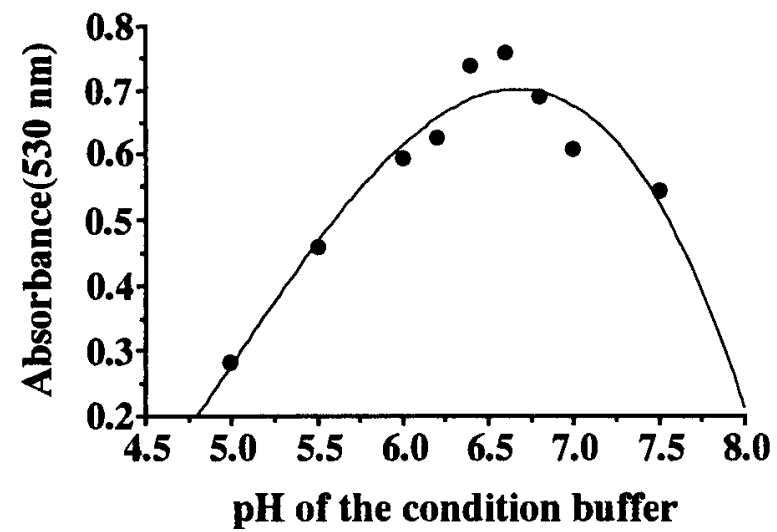

Fig. 1. $\mathrm{pH}$ - $p$-phenylenediamine oxidase activity plots for adult Thoroughbred horses. Approximately $\mathrm{pH} 6.6$ of the buffer was the optimum condition for the reaction of serum oxidase activity to $p$-phenylenediamine.

condition buffer [3]. The pH-p-phenylenediamine Ox activity plots for Thoroughbred horses were given (Fig. 1). The peak value of the $\mathrm{A}_{530}$ was reached at the $\mathrm{pH} 6.6$, so this $\mathrm{pH}$ was considered as the optimum $\mathrm{pH}$ for the measurement of the Ox activity.

Serum Cp concentration was measured directly by the immunological assay described [18] with some modification. In the SRID method, purified antibody to equine $\mathrm{Cp}$ purified by equine $\mathrm{Cp}$ binding sepharose $4 \mathrm{~B}$ affinity chromatography was employed, and a more reliable assay system was established. The rang of the SRID was extended (1.6 to $100 \mathrm{mg} / \mathrm{d} l$ ) compared with previous report [18]. A higher degree of correlation $(r=0.928)$ was still found between $\mathrm{Cp}$ concentration and oxidase activity of sera from clinically healthy adult horses in this study (Fig. 2).

Serum Cp concentration in human plasma can be indirectly calculated by the data on serum Ox activity. However, the Ox activities of certain amounts of $\mathrm{Cp}$ have variation in species and age $[2,18,21]$. Therefore, the relationship between $\mathrm{Cp}$ concentration and its Ox activity in adult equine sera was explored. The value of Ox activity/ $\mathrm{Cp}$ in adult thoroughbred horses was similar to that in human beings [17].

The ratio of $\mathrm{Ox} / \mathrm{Cp}$ in adult Thoroughbred horses, which was given in this study, would contribute to the calculation of equine $\mathrm{Cp}$ concentration from its $\mathrm{Ox}$ activity. This ratio might be used in adult horses only, because this value in newborn foals was indicated to be less than that of adult horses $[2,18]$. Further study is required to be confirm the ratio of $\mathrm{Ox} / \mathrm{Cp}$ in younger horses.

The ratio of the $\mathrm{Ox}$ activity to antigenic $\mathrm{Cp}$ concentration may indicate the relationship between holo- and apo-Cps. The Ox activity in serum samples represents the concentration of copper binding Cp (holo-Cp) [1], and Cp concentration measured by immunological method in this study indicate both holo-Cp and copper-free Cp (apo-Cp). Therefore, this ratio would be of value to analyze holo-Cp content. Serum Ox activity in newborn foals was reported

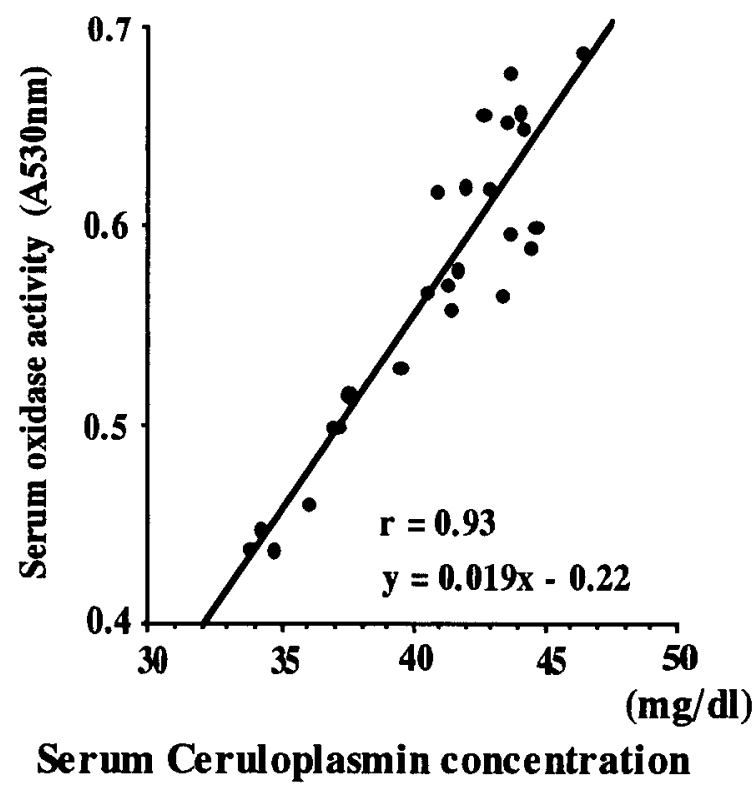

Fig. 2. Correlation between serum ceruloplasmin and oxidase activity in adult Thoroughbred horse sera. r: correlation coefficient.

to be one-fifth that in adult horses [2]. This may indicate that the ratio of holo- and apo-Cp in newborn foals might be different from that in adult horses, or that the ability to bind to copper would be immature in newborn foals. This difference of the $\mathrm{Ox} / \mathrm{Cp}$ ratio between newborn foals and adults might have some relationship to orthopedic abnormalities in foals induced by copper-deficiency [4, 8].

In conclusion, the optimum $\mathrm{pH}$ for the measurement of $p$-phenylenediamine Ox activity in equine serum was given, and the relationship between antigenic $\mathrm{Cp}$ concentration and its Ox activity was established in sera from adult thoroughbred horses. The optimum $\mathrm{pH}$ of the condition buffer for the reaction of $p$-phenylenediamine with serum Ox originating from serum ceruloplasmin was 6.6. In adult horses, serum $\mathrm{Cp}$ concentrations were measured by single radial immunodiffusion method with the affinity-purified antibody to equine plasma $\mathrm{Cp}$ and compared with its $\mathrm{Ox}$ activity. Efficient co-relation was given between $\mathrm{Cp}$ concentration and Ox activity in the sera $(r=0.928)$. These results might contribute to the calculationof antigenic $\mathrm{Cp}$ concentration from its $\mathrm{Ox}$ activity, the analysis of holo- $\mathrm{Cp}$ content in serum, and the research for copper metabolism in Thoroughbred horses.

\section{REFERENCES}

1. Auer, D. E., Ng, J. C., and Seawright, A. A. 1988. Aust. Vet. J. 65: 317-320.

2. Bell, J. U., Lopez, J. M., and Bartos, K. D. 1987. Comp. Biochem. Physiol. 87: 561-564.

3. Bingley, J. B. and Dick, A. T. 1969. Clin. Chim. Acta 25: 480-482.

4. Bridges, C. H. and Harris, E. D. 1988. J. Am. Vet. Med. 
Assoc. 193: 215-221.

5. Bridges, C. H. and Moffitt, P. G. 1990. Am. J. Vet. Res. 51: 275-280.

6. Bridges, C. H., Womack, J. E., Harris, E. D., and Scrutchfield, W. L. 1984. J. Am. Vet. Med. Assoc. 185: 173-178.

7. Calabrese, L., Malatesta, F., and Barra, D. 1981. Biochem. J. 199: 667-673.

8. Cymbaluk, N. F. and Smart, M. E. 1993. Equine Vet. J. (Suppl.) 16: 19-26.

9. Deutsch, H. F., Kasper, C. B., and Walsh, D. A. 1962. Arch. Biochem. Biophys. 99: 132-135.

10. Holmberg, C. G. and Laurell, C. B. 1948. Acta Chem. Scand. 2: $550-556$.

11. Houchin, O. B. 1958. Clin. Chem. 4: 519-523.

12. Inaba, T. and Frienden, E. 1967. J. Biol. Chem. 242: 47894795.

13. Knight, D. A., Gabel, A. A., Reed, S. M., Embertson, R. M.,
Tyznik, W. J., and Bramlage, L. R. 1985. Proc. Am. Assoc. Equine Pract. 31: 445-461.

14. Kovar, J. and Pitrincova, J. 1986. J. Chromatography 368: 468-471.

15. Manolis, A. and Cox, D. W. 1980. Prep. Biochem. 10: 121132.

16. Medda, R., Cara, N., and Floris, G. 1987. Prep. Biochem. 17: 447-454.

17. Noyer, M., Dwulet, F. E., Hao, Y. L., and Putnam, F. W. 1980. Anal. Biochem. 102: 450-458.

18. Okumura, M., Fujinaga, T., Yamashita, K., Tsunoda, N., and Mizuno, S. 1991. Am. J. Vet. Res. 52: 1979-1985.

19. Rice, E. W. 1962. Anal. Biochem. 3: 452-456.

20. Ryden, L. 1972. Eur. J. Biochem. 28: 46-50.

21. Smith, J. E. and Cipriano, J. E. 1987. Vet. Pathol. 24: 354356. 